Fall 2003

\title{
Editorial Introduction: Theory and Method in Symbolic Interactionism
}

Philip Manning

Cleveland State University, p.manning@csuohio.edu

Follow this and additional works at: https://engagedscholarship.csuohio.edu/clsoc_crim_facpub

¿vid R. Maines

Oakland University

How does access to this work benefit you? Let us know!

Publisher's Statement

Published as Manning, Philip and D. R. Maines. 2003. "Editorial Introduction: Theory and Method in Symbolic Interactionism." Symbolic Interaction 26(4):497-500. (c) 2003 by the Society for the Study of Symbolic Interaction. Copying and permissions notice: Authorization to copy this content beyond fair use (as specified in Sections 107 and 108 of the U. S. Copyright Law) for internal or personal use, or the internal or personal use of specific clients, is granted on behalf of the Society for the Study of Symbolic Interaction for libraries and other users, provided that they are registered with and pay the specified fee via Rightslink ${ }^{\circledR}$ on JSTOR (http://www.jstor.org/r/ucal) or directly with the Copyright Clearance Center, http://www.copyright.com.

\section{Original Citation}

Manning, Philip and D. R. Maines. 2003. "Editorial Introduction: Theory and Method in Symbolic Interactionism." Symbolic Interaction 26(4):497-500.

\section{Repository Citation}

Manning, Philip and Maines, David R., "Editorial Introduction: Theory and Method in Symbolic Interactionism" (2003). Sociology \& Criminology Faculty Publications. 8.

https://engagedscholarship.csuohio.edu/clsoc_crim_facpub/8

This Editorial is brought to you for free and open access by the Sociology \& Criminology Department at EngagedScholarship@CSU. It has been accepted for inclusion in Sociology \& Criminology Faculty Publications by an authorized administrator of EngagedScholarship@CSU. For more information, please contact library.es@csuohio.edu. 


\title{
Editorial Introduction: Theory and Method in Symbolic Interactionism
}

\author{
Philip Manning \\ Cleveland State University \\ David R. Maines \\ Oakland University
}

Part of the excitement of symbolic interactionism is that it has always fused theory and a set of methods. Herbert Blumer's felicitous term captured the spirit of both the groundbreaking comparative efforts of the curmudgeonly William Graham Sumner, whose extraordinary work, Folkways (1906), still has currency today, and of the varied, rich work of many scholars associated with Chicago sociology. The tradition of symbolic interactionism testifies to the continuing vitality of American sociology. Therefore, this special issue represents the latest chapter in a long book of accomplishments that fuse theoretical insight and empirical research in compelling ways. The symbolic interactionist tradition requires scholars to absorb, cultivate, and extend it. All the papers in this special issue contribute to this venture.

We are particularly pleased to note that the future of symbolic interactionism is global, although its origins are thoroughly American. As editors, we were delighted to receive quality papers from not just the United States but also England, Ireland, Canada, Australia, China, and elsewhere. This global community of scholars has addressed varied issues. They have provided theoretical commentary and technical information with which to solve methodological problems, reframe epistemological issues, and challenge conventional views held by sociologists, whether interactionists or otherwise.

To represent the fullest possible range of issues, we accepted several full-length articles, but in other cases we asked authors to reduce the length of their articles significantly. By doing so, we have been able to include eleven articles written by both senior and junior scholars and have organized them under various issues that are common to all social research but are of special interest to interactionists.

Of the first three articles, two address issues familiar to interactionist interests and the third is rather less familiar. Norbert Wiley leads with his analysis of the self

Direct all correspondence to Philip Manning, Rhodes Tower, 2121 Euclid Ave., Cleveland State University, Cleveland, $\mathrm{OH} 44115$; e-mail: p.manning@csuohio.edu. 
and presents a perspective based on both Lacanian and pragmatist dimensions. $\mathrm{He}$ theorizes that the self is perpetually poised for breakdown but is nonetheless held together by a self-fulfilling process, itself shored up by belief and confidence. Wiley has opened up a rich vein of future research by showing that some strands of contemporary psychoanalysis can complement the ideas of Cooley and Mead. In fact, the exciting dialogue between psychoanalysts interested in object relations and theoretically minded sociologists has been a feature of American sociology since at least Talcott Parsons's work in the 1940s. Wiley's article extends arguments that continue to have broad application.

Robin Williams's article is an analysis of identity that extends ideas from both Goffman and Garfinkel. He argues that we should understand and theorize in terms of the social processes that bring identity into being. Drawing on his ethnography of crime scene examiners, Williams shows how people situate identity in ordinary local actions involving discursive and reconstructive practices. The theoretical implications of his arguments are subtle, and therefore their huge impact can be missed. In effect, Williams challenges sociologists to develop theories that emerge out of social practices. He criticizes approaches that apply generic categories to disparate groups. To realize this research agenda requires an approach that draws on both ethnomethodological and symbolic interactionist perspectives. ${ }^{1}$

Although these two articles on self and identity fit well in the conventional interactionist gestalt, Jeffery Ulmer and Mindy Wilson's article most likely does not. They challenge the conventional view that interactionism and statistical analysis are somehow incompatible. While addressing both the possibilities and the limitations of quantitative analysis, they nonetheless show how these procedures find some fit with several domain interactionist concepts-meaning, variation, comparisons, situations, contexts, and probability.

We organized the remaining eight articles into four topics for readers to further discuss and consider. The first topic is grounded theory, and the central issue is how to deal with complexity in data analysis. Adele Clarke frames her analytic approach around postmodernist challenges and proposes a series of steps that she calls "situational analysis." These steps involve constructing various maps - of situations, of social worlds, of location on analytic dimensions - through which the analyst might better grapple with complexity. In more technical terms, Brian Castellani, John Castellani, and S. Lee Spray present a software procedure for dealing with complex quantitative data in a way that blurs quantitative and qualitative boundaries while remaining consistent with post-positivistic epistemologies. In both articles, readers will find these approaches applied to empirical cases, which taken together might help to solve analytic problems involving complexity.

The next two articles address issues in the epistemological debates over insider and outsider research roles and identities. We are particularly pleased to publish these two fine papers now, as a small tribute to the pathbreaking work on insider/ outsider research of the late Robert Merton. Both Abdi Kusow and Steven Ortiz problematize the contention that insider status provides superior ethnographic data. 
Kusow describes how his being a Somali immigrant studying Somali immigrants gave him insider access in some situations, but being a male rendered him an outsider in others. This experience leads him to make the point that a Caucasian Western woman may under some circumstances have greater access to the social worlds of Somali immigrants than do male Somali researchers. Ortiz uses the phrase "muted masculinity" to describe how, as a male researcher, he managed field relationships in his research on wives of professional athletes. He proposes this muted masculinity as a strategy for dealing with insider/outsider relations permeated by uncertainty.

The next topic pertains to the biological aspects of human life, and both articles express the view that social scientists should take biology more seriously. David Franks limits his analysis to the field of neuroscience and points out that new approaches in that field are consistent with a number of constructionist assumptions held by interactionists. Robert Dingwall, Brigitte Nerlich, and Samantha Hillyard focus on certain recent developments in genetics and critically address recent arguments on the biological basis of criminal conduct. Both articles call for greater mutual understanding by biological and social scientists alike of the functions of biological and environmental processes. This greater understanding will require a specification of the role sociological knowledge can play in the biological investigation of environmental influences. The contribution of both papers is to initiate an informed analysis of this.

Our final topic pertains to Erving Goffman and his work. For many symbolic interactionists, Goffman is still a role model more than twenty years after his death. In a very important correction to our understanding of Goffman's early work, Gregory Smith uses Goffman's master's thesis to show that Goffman's innovative qualitative methodology actually emerged as a response to the limitations he encountered while trying to conduct quantitative research. Smith's article fills a gap in our knowledge of the intellectual development of one of the most important sociologists associated with symbolic interactionism. But perhaps even more important, Smith offers a new vantage point from which to appreciate Goffman's contributions to sociology. Finally, we are delighted to publish a paper by one of the most significant sociologists in the United States: Howard Becker. His article provides a compelling reexamination of one of the most influential books in American sociologyGoffman's Asylums - in order to clarify Goffman's comparative procedure for transcending in situ vocabularies. Thus we can also read Becker's paper as a general contribution to the methodology of qualitative sociology.

The success of symbolic interactionism requires each generation of scholars to absorb and cultivate its perspective. However, the best tribute that can be paid to symbolic interactionism is to allow the field to develop in new ways, to pursue ideas that earlier generations of scholars did not and perhaps could not imagine. We believe that the articles in this special issue contain both the cultivated appreciation of symbolic interactionism that preserves the field and the willingness to take the intellectual risks that may transform it. In studying the symbolic interactionism of the past, we must remember how radical a perspective it then was. Our intellectual 
risk-taking today must be able to stand comparison to the past; otherwise symbolic interaction will atrophy. These articles, we believe, contribute in these two ways: they show a cultivated appreciation of symbolic interactionism and a willingness to take the risks that are necessary if symbolic interactionism is to have continuing relevance.

\section{NOTE}

1. Williams's paper extends arguments that he has recently developed in an important book on the concept of identity, Identity Matters.

Post-print standardized by MSL Academic Endeavors, the imprint of the Michael Schwartz Library at Cleveland State University, 2015 